\title{
Distribution of Polycyclic Aromatic Hydrocarbons (PAHs) and Trace Metals in Ejamah-Ebubu Oil Spill Site
}

\author{
Onyinyechi N. Akomah" ${ }^{*}$, Gideon 0. Abu² \\ ${ }^{1}$ Department of Microbiology Technology, School of Science Laboratory Technology, College of Natural and \\ Applied Sciences, University of Port Harcourt, Port Harcourt, Nigeria \\ ${ }^{2}$ Department of Microbiology, College of Natural and Applied Sciences, University of Port Harcourt, \\ Port Harcourt, Nigeria \\ Email: "onyiakomah@yahoo.com
}

Received 10 July 2015; accepted 26 July 2015; published 31 July 2015

Copyright $@ 2015$ by authors and OALib.

This work is licensed under the Creative Commons Attribution International License (CC BY).

http://creativecommons.org/licenses/by/4.0/

(c) (i) Open Access

\begin{abstract}
The distribution of polyaromatic hydrocarbons (PAHs) at different georeferenced sampling points: Nwata A, Nwata B, Nwata 3', Ochani and Eyeyaro in one of the most contaminated mangrove swamp in Nigeria, Ejamah-Ebubu oil spill site was studied. The physico-chemical analysis of the sediment samples and trace metals were also conducted. PAHs were analyzed using gas-chromatography flame ionization detection while metals with atomic absorption spectrophotometry (AAS). The result showed that the total PAHs (summation of 16 US EPA priority PAHs) were present at all sampling points and the concentration ranged from 0.070 to $5.521 \mathrm{ppm}$ with Nwatu $A>$ Nwatu B > Ochani > Egeyaro > Nwatu 3'. The pH of the site is acidic. The concentration of trace metals for most sampling points is iron $>$ chromium $>$ lead $>$ nickel $>$ vanadium. Our result indicates that the concentration of PAHs is at level higher than the permitted level therefore; it is recommended that Ejamah-Ebubu oil spill site be remediated.
\end{abstract}

\section{Keywords}

Polyaromatic Hydrocarbons, Gas Chromatography, Spectrophotometer, Trace Metals

Subject Area: Biochemistry

\section{Introduction}

Polycyclic aromatic hydrocarbon (PAH) is a common term for high molecular aromatic hydrocarbons. PAHs

${ }^{*}$ Corresponding author.

How to cite this paper: Akomah, O.N. and Abu, G.O. (2015) Distribution of Polycyclic Aromatic Hydrocarbons (PAHs) and Trace Metals in Ejamah-Ebubu Oil Spill Site. Open Access Library Journal, 2: e1642.

http://dx.doi.org/10.4236/oalib.1101642 
constitute a class of hazardous organic chemicals consisting of two or more fused benzene rings in linear, angular, or cluster arrangements [1] [2].

The carcinogenicity of PAHs has been known since the 1930s. But it was not until the 1970s that an understanding of the mechanisms of carcinogenesis by PAHs emerged [3]. The pioneering research of Miller and Miller [3] has shown that cancer induction by PAHs is a complex and multistep process that depends on many factors. These factors include size of the PAH molecule, polarity constraints, stereochemistry and chemical activity of the metabolites, and electronic factors that affect the binding of metabolite to macromolecules [4]. PAHs are known for their carcinogenic effects, while their ecotoxicological effects are less emphasized, since they are not considered to have acute toxicity of any significance. This is normally linked to the very low water solubility and bioavailability of these compounds, but this also means that it is extremely difficult to design and carry out toxicity tests [5].

PAHs behave alike in soil or water. They are not easily degraded by microorganisms. Polycyclic aromatic hydrocarbons provide more detailed compositional data that can be used to identify both the source and extent of degradation of released crude oil [6]-[8] largely because PAHs are more complex and more resistant to biodegradation than alkanes. Although PAHs commonly represent less than $2 \%$ of the bulk composition of crude oil, they include toxic compounds that can be of concern in the longer term. Polycyclic aromatic hydrocarbons (PAHs) are of most concern due to their toxicity, low volatility, resistance to microbial degradation and high affinity for sediment [9]. Recently concern has turned to the interference of PAHs with hormone system and their potential effects on reproduction, as well as their ability to depress immune function [10].

The objectives of our study were i) to estimate the level of PAHs in a historic contaminated site of more than 40 years; ii) to establish a georeferenced distribution of molecular pollutants in a typical Niger Delta wetland; iii) to determine physico-chemical parameters and trace metals present at the site.

\section{Methodology}

\subsection{Microcosm Setup for Molecular Georeferening}

Sediment sample was collected by stratified sampling method at depths $20 \mathrm{~cm}$ and $40 \mathrm{~cm}$, from Egbara Stream (Ewenta Egbara) in Eleme, Rivers State, Nigeria. Egbara Stream is a swampy wetland and its choice was informed by the heavy crude oil it received from a damaged Trans Niger pipeline belonging to Shell Petroleum Development Company (SPDC) Limited more than 50 years ago. The location of sampling points was marked using global positioning system. (Model GPSMAP76, Am, serial no: 91090835). The GPS reading of the sampling points are: Egeyaro (A) (N04 $\left.45^{\prime} 23.8^{\prime \prime E} 007^{\circ} 09^{\prime} 47.0^{\prime \prime}\right)$, Ochani (B) (N04 46'19.9"E 007 09'33.5"), Nwatu

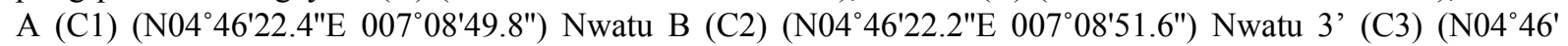
23.9"E $\left.007^{\circ} 09^{\prime} 07.0^{\prime \prime}\right)$. Analyzed samples would indicate the distribution of molecules of potential concern (MOPC)-polyaromatichydracarbons-with time (Figure 1).

\subsection{Physico-Chemical Properties}

\subsubsection{Determination of Nitrate}

Nitrate was estimated using the Brucine method as described by Allen et al. [11]. The procedure involved weighing about $1 \mathrm{ml}$ of the test sample into a clean test tube, then $0.5 \mathrm{ml}$ of $2.5 \% \mathrm{v} / \mathrm{v}$ Brucine solution in acetic acid was added to the tube. Thereafter, $2 \mathrm{ml}$ of conc. $\mathrm{H}_{2} \mathrm{SO}_{4}$ was added and thoroughly mixed. This was allowed to stand for about 15 - 30 minutes. The colour the developed was measured at $460 \mathrm{~nm}$ using distilled water as blank. The nitrate concentration in the sample was extrapolated from standard graph prepared from the nitrate stock.

Calculation

$$
\mathrm{NO}_{3}^{-}=\mathrm{N}(\mathrm{mg} / \mathrm{l})=\frac{\mathrm{C}(\mathrm{mg}) \times 1000}{\text { aliqout }(\mathrm{vol} \mathrm{ml})}
$$

where $\mathrm{C}=\mathrm{mg} \quad \mathrm{NO}_{3}^{-}=\mathrm{N}$ obtained from the graph.

\subsubsection{Determination of Phosphate}

Phosphate was determined using the ascorbic acid method as determined in the standard methods for examina- 


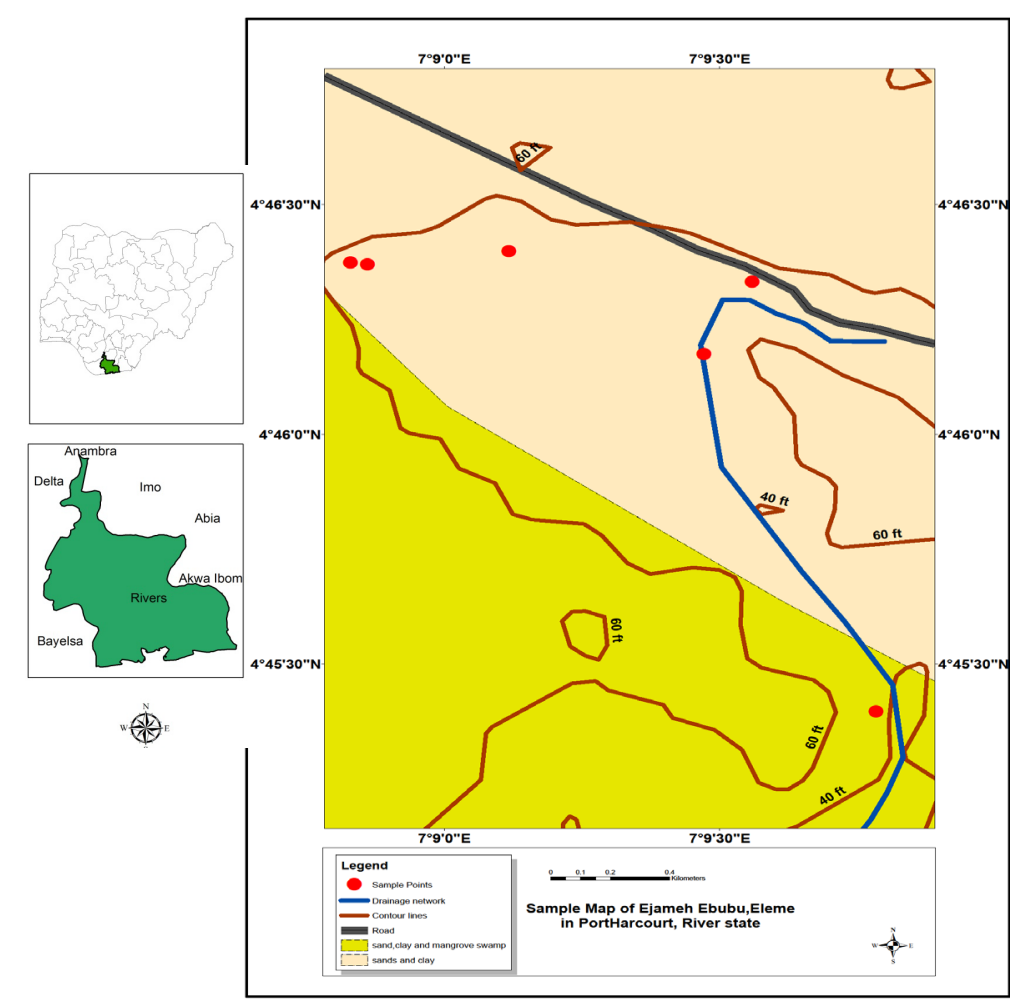

Figure 1. Sample Map of Ejamah Ebubu, Eleme in Port Harcourt, River State, Nigeria.

tion of water and waste water, APHA [12]. About $50 \mathrm{ml}$ of sample was pipetted into a clean, dry $125 \mathrm{ml}$ Erlenmeyer flask. Then $0.05 \mathrm{ml}$ (1 drop) of phenolphthalein indicator was added. A $5 \mathrm{~N} \mathrm{H}_{2} \mathrm{SO}_{4}$ solution was added drop wise with the development of a red colour. Then $8 \mathrm{ml}$ of the combined reagents made up of $50 \mathrm{ml}, 5 \mathrm{~N}$ $\mathrm{H}_{2} \mathrm{SO}_{4}, 5 \mathrm{ml}$, potassium antimony tartrate solution $(1.372 \mathrm{~g}$, potassium antimony tartrate in $500 \mathrm{ml}$ distilled water, $15 \mathrm{ml}$ ammonium molybdate solution) (20 g ammonium molybdate crystal in $500 \mathrm{ml}$ distilled water); and 30 $\mathrm{ml}$ ascorbic acid solution $(1.76 \mathrm{~g}$ ascorbic acid in $100 \mathrm{ml}$ distilled water) were added and thoroughly mixed and allowed to stand for $10-30$ minutes. The absorbance of each sample was measured at $880 \mathrm{~nm}$ using the reagent blank as the reference solution.

Calculation

$$
\mathrm{PO}_{4}^{3-}=\mathrm{P}(\mathrm{mg} / \mathrm{kg})=\frac{\mathrm{C}(\mathrm{mg}) \times \text { extraction vol. } \times 1000}{\text { aliquot } \operatorname{vol}(\mathrm{ml}) \times \operatorname{sample}(\mathrm{g})}
$$

where $\mathrm{C}=\mathrm{mg} \quad \mathrm{PO}_{4}^{3-}=\mathrm{P}$ obtained from the graph.

\subsubsection{Determination of Sulphate}

The method used for the determination of sulphate was the turbidometric method adopted from APHA [12]. Extraction was carried out by weighing $5 \mathrm{~g}$ of sediment sample into $100 \mathrm{ml}$ Erlenmeyer flask. To this was added 25 $\mathrm{ml}$ of the extracting solution and shaken for 30 minutes on a mechanical shaker. The suspension was filtered through whatman No. 42 paper into a $25 \mathrm{ml}$ volumetric flask to which was added $10 \mathrm{ml}$ of the extract. To this, distilled water was added to bring the volume to approximately $20 \mathrm{ml}$, one milliliter of gelatin- $\mathrm{BaCl}_{2}$ reagent was added and the volume made up to $25 \mathrm{ml}$ with distilled water. The content was thoroughly mixed and allowed to stand for 30 minutes. The standards were treated in the same way. The contents of the tube were shaken and the optical density was measured at $420 \mathrm{~nm}$ within 30 minutes. The $\mathrm{SO}_{4}^{2-}$ content of the sediment sample was read off from the standard curve drawn using standard reading.

Calculation 


$$
\mathrm{SO}_{4}^{2-}=\mathrm{S}(\mathrm{mg} / \mathrm{kg})=\frac{\mathrm{C}(\mathrm{mg}) \times \text { extractant vol } \times 1000(\mathrm{ml})}{\text { aliquot } \operatorname{vol}(\mathrm{ml}) \times \operatorname{sample}(\mathrm{g})}
$$

where $\mathrm{C}=\mathrm{mg} \mathrm{SO}_{4}^{2-}=\mathrm{S}$ obtained from the graph.

\subsubsection{Procedure for Metal Analysis}

Atomic absorption (using Buck Scientific Atomic Absorption Spectrometer 205A) has been found to be a satisfactory technique for the determination of metals in samples. About $2 \mathrm{~g}$ of the sample was digested with $2 \mathrm{ml}$ conc. $\mathrm{H}_{2} \mathrm{SO}_{4}$ and diluted to $30 \mathrm{ml}$. The $248.3 \mathrm{~nm}$ wavelength was selected and air and gas flows were adjusted. A calibration curve was prepared from the standard range by setting the top standard to suitable scale deflection and $0 \mathrm{ppm}$ standard. The calibration was used to obtain the ppm of the metal of choice in the sample solution.

Calculation

$$
\operatorname{Metal}\left(\mathrm{mg} / 100 \mathrm{~g}^{-1}\right)=\frac{\mathrm{C}(\mathrm{ppm}) \times \text { solution volume }(\mathrm{ml})}{10 \times \operatorname{sample}(\mathrm{wt}) \mathrm{g}}
$$

\subsection{5. $\mathrm{pH}$ and Conductivity Measurement}

The $\mathrm{pH}$ of the sediment was measured using a $\mathrm{pH}$ meter (Jenway 015 model) while the conductivity was measured using the conductivity meter (SC-300).

\subsubsection{Gas Chromatographic (GC) Analysis}

Gas chromatographic analysis was done to determine the level of specific crude oil components in the samples before and after treatment. It was also to determine the extent of crude oil disappearance resulting from either biodegradation or other physical/chemical weathering processes. One way of distinguishing one from the other is by evaluating the ratios of target hydrocarbon concentration of the biomarkers pristine and phytane.

Gas chromatographic analysis was performed using Unican Pro GC. Crude oil was extracted from the sediment using dichloromethane as extracting solvent. The column length was $30 \mathrm{~m}$ with an ID of $0.25 \mathrm{~mm}$. The initial and final column temperatures were $60^{\circ} \mathrm{C}$ and $300^{\circ} \mathrm{C}$ respectively with 20 minutes and 28 minutes as initial and upper times, respectively. Injector temperature was $300^{\circ} \mathrm{C}$ and detector temperature was $350^{\circ} \mathrm{C}$ with helium as carrier gas at 15 psi. Hydrogen was used as fuel at psi and compressed air as oxidant at $25 \mathrm{psi}$.

\subsection{Statistical Analyses}

Analysis of Variance (ANOVA) was applied to test if there is significant difference between means of various tested parameters

\section{Results and Discussion}

The result of the analysis of physico-chemical properties and the metal content of the sediment sample are contained in Table 1. The $\mathrm{pH}$ of the various sampling points is acidic, ranges from 3.45 to 5.34. Nwatu B recorded 3.45 which is higher than Nwatu A, Ochani also have a high $\mathrm{pH}$ but down the stream $\mathrm{pH}$ decreases. The conductivity of sampling points is high indicting the present of ions. Nwatu B recorded higher value $(20 \mathrm{us} / \mathrm{cm})$ than Nwatu A (12 us $/ \mathrm{cm})$. Nwata 3' recorded the highest value of $250 \mathrm{us} / \mathrm{cm}$. The conductivity of the various sampling points increases down the stream toward the Bonny River (Table 1). This is supported with the increase in the concentration of salts, ions and metals that are measured.

\subsection{Salt Content}

The Nitrate concentration of sampling points ranges from 4.2 - 8.9 (ppm). Nwata A has a higher nitrate concentration than Nwata B $4.2 \mathrm{ppm}$. Nwatu3' have the highest value of $8.9 \mathrm{ppm}$ The Phosphate level of the sampling point ranges from $38.63-53.80(\mathrm{ppm})$. Nwata A recorded a higher phosphate concentration $41.6 \mathrm{ppm}$ than Nwatu B while Nwatu3' have the highest value $53.80 \mathrm{ppm}$.

The sulphate level of the sampling point ranges from $20 \mathrm{ppm}-75 \mathrm{ppm}$. Nwatu A recorded a higher sulphate level $32 \mathrm{ppm}$ than Nwatu B $20 \mathrm{ppm}$. Ochani recorded the highest level.The Nitrate, phosphate and sulphate salts 
Table 1. Physciochemical properties, salts, TPH and PAHs of various sampling points.

\begin{tabular}{cccccc}
\hline Parameter & Nwata A & Nwata B & Nwata 3 & Egeyaro & Ochani \\
\hline $\mathrm{pH}$ & $4.54 \pm 0.07$ & $3.45 \pm 0.08$ & $5.34 \pm 0.07$ & $4.26 \pm 0.14$ & $3.46 \pm 0.05$ \\
$\mathrm{Cond}(\mathrm{us} / \mathrm{cm})$ & $12 \pm 2$ & $20 \pm 2$ & $250 \pm 2$ & $158 \pm 2$ & $150 \pm 2$ \\
$\mathrm{PO}_{4}^{3-}(\mathrm{ppm})$ & $5.27 \pm 0.1$ & $4.20 \pm 0.3$ & $8.90 \pm 0.2$ & $4.97 \pm 0.2$ & $5.67 \pm 0.2$ \\
$\mathrm{PO}_{4}(\mathrm{ppm})$ & $41.60 \pm 0.7$ & $39.19 \pm 0.4$ & $53.80 \pm 0.9$ & $45.70 \pm 0.9$ & $38.63 \pm 1.4$ \\
$\mathrm{SO}_{4}(\mathrm{ppm})$ & $32 \pm 2$ & $20 \pm 2$ & $38 \pm 2$ & $54 \pm 2$ & $75 \pm 1$ \\
$\mathrm{TPH}(\mathrm{ppm})$ & $9892.2 \pm 9.7$ & $7578.46 \pm 6.8$ & $98.04 \pm 0.4$ & $312.17 \pm 2.0$ & $1165.3 \pm 1.2$ \\
$\mathrm{PAH}(\mathrm{ppm})$ & $5.521 \pm 0.01$ & $4.155 \pm 0.01$ & $0.070 \pm 0.002$ & $0.131 \pm 0.002$ & $0.768 \pm 0.003$ \\
\hline
\end{tabular}

are present at all sampling points. When a major oil spill occurs, the supply of carbon is dramatically increased and the availability of nitrogen and phosphorus generally becomes the limiting factor for oil degradation [13], [14] this is evidence in the result (Table 1). Nitrate concentration is very low (Table 1) since $150 \mathrm{mg}$ of nitrate is required to convert $1 \mathrm{~g}$ hydrocarbon [15] to cell material hence persistence of the contaminant. Nitrate is limiting at all sampling points except Nwatu 3' which has nitrate concentration of 8.90 (ppm) and TPH 98.04 (ppm)

The phosphate concentration is moderate since $30 \mathrm{mg}$ of phosphate is required to convert $1 \mathrm{~g}$ of hydrocarbon. Phosphate is limiting at Nwatu A and Nwatu B sampling points due to the high amount of TPH at these points, Nwatu A $\{9892.2$ (ppm) $\}$ and Nwatu B $\{7578.46$ (ppm) $\}$. At Nwatu 3', Egeyaro and Ochani sampling points phosphate is not limiting, as evidence in the result (Table 1 ).

The presence of sulphate at the various sampling points (Table 1) point to the fact that other non oxygen terminal electron acceptors; could be utilized by anaerobic bacteria which are often present in oxygen depleted environment. Meckenstock et al. [16] demonstrated that sulphate can be use as a terminal electron acceptor when they enriched a sulphate-reducing culture from a contaminated aquifer material by adding naphthalene as sole carbon and energy source. The sulphate concentration increases down the stream toward the Bonny River.

\subsection{TPH and PAHs Content}

The TPH concentration of the sampling point ranges from $98.04 \mathrm{ppm}$ to $9,892.20 \mathrm{ppm}$ with Nwata A recorded the highest value. The PAH concentration ranges from $0.070 \mathrm{ppm}-5.291 \mathrm{ppm}$ with Nwatu A recorded the highest value. The concentration of polyaromatic hydrocarbons (PAHs) in the sediment from various sampling points of Ejamah Ebubu oil spill contaminated site at 0.05 (95\%) level of confidence indicates significant difference between means of various sampling points Nwata A (N04 $46^{\prime} 22.4^{\prime \prime}$ E $\left.007^{\circ} 08^{\prime} 49.8^{\prime \prime}\right)$ and Nwata B (N04 46'22.2"E 007 08'51.6") (Table 1) both have concentrations of PAHs above the target value of 1mg/kg for a total of ten PAHs set by the Department of petroleum resources (DPR) in Nigeria (EGASPIN), [17]; while Nwata 3' (N04 46'23.9"E 007 09'07.0"), Egeyaro (N04 45'23.8"E 007 09'47.0") and Ochani (N04 46' 10.5"E $\left.007^{\circ} 09^{\prime} 28.3^{\prime \prime}\right)$ showed lower. The result shows the down the stream towards the Bonny River the concentration of PAHs decreases, this could be attributed to factors like spreading, evaporation, biodegradation. It supports the general observation that concentration of PAHs in sediment decreases with increasing distance to point source [18].

About 13 (81.25\%) of the 16EPA PAHs were detected at all the sampling points (chromatogram not showed). Napthalene, acenaphthene, fluorene, phenanthrene, anthracene, fluoranthene, benzo (a)anthracene, chrysene, benzo (b)fluoranthene, benzo (a)pyrene, dibenz (a, h, ) anthracene, indeno (1,2, 3-cd)pyrene and indeno (1, 2, 3)pyrene which is not a "16 EPA PAHs" showing that the environment is among the area labeled as contaminated sites. Benzo@anthracene, chrysene, benezo (b)fluoranthene, benezo (a)pyrene, Indeno $(1,2,3)$ pyrene, dibenz $(\mathrm{a}, \mathrm{h})$ anthracene and indeno (1, 2, 3-cd) which are suspected as carcinogens and mutagens [10] [19] are presence at all points.

The fingerprints showed the level of high-molecular-weight (HMW) PAHs detected at various sampling points are higher than low-molecular-weight (LMW) PAHs (chromatogram not showed) indicating greater per- 
centage of combustion-related PAHs (pyrogenic sources) than petroleum products [20]. The high-molecu-larweight PAHs such as the four-, five-, six-ring PAHs are relatively stable and therefore, can be useful as diagnostic constituents of petroleum; the low-molecular-weight PAHs such as naphthalene and phenanthrene are more attributable to biodegradation and other forms of attenuation. The dominance of a group of PAHs a group of PAHs ( eg benezo (b)fluranthene, indeno (1, 2, 3-cd) pyrene, indeno $(1,2,3)$ pyrene etc) which are pyrolytic PAHs over other identified as fossil PAHs (eg chrysene, phenanthrene), may be an indication that pyrolysis might have taken place; this is in agreement with Boll, et al. [20]. This may be why phenanthrene/anthracene $(\mathrm{Ph} / \mathrm{An})$ of all sampling points are below unity (one) while the benzo (a) anthrancene/ chrysene $(\mathrm{BA} / \mathrm{Ch})$ ratio is above unity.

The distribution of the n-alkane components of the analyzed sample presented in Table 1 has the concentration of total petroleum hydrocarbon (TPH) of all sampling point is above the DPR target $[17] 30 \mathrm{mg} / \mathrm{kg}$. The chromatograms (chromatograms not showed) indicate $\mathrm{n}-\mathrm{C}_{8}-\mathrm{C}_{40}$ with the isoprenoids pristine and phytane for all sampling point. This is in agreement with result of other workers [14] that saturates usually are the most abundant constitutes in crude oil. Alkanes in the $\mathrm{C}_{10}$ to $\mathrm{C}_{26}$ range are considered the most readily and frequently utilized hydrocarbons [21] [22].

The presence of $n-C_{8}-C_{40}$ and the isopreniods at the various sampling points after the spill of greater than forty years shows the state of the contamination; the isoprenoids which are used as biomarkers for evaluation of biodegradation [23] since they are somewhat more resistant to biodegradation than n-alkane with similar boiling points $\left(\mathrm{C}_{17}, \mathrm{C}_{18}\right)$, but they are used to monitor the earliest stages of biodegradation treatment program, as they are known to be biodegradable under natural conditions [24]. The ratio of pristane to phytane $(\mathrm{Pr} / \mathrm{Ph})$ of all sampling points is above unity which is in agreement; that $\mathrm{Pr} / \mathrm{Ph}$ ratio is a source indices of the spilled oil's depositional environments. The high $\mathrm{Pr} / \mathrm{Ph}$ ratios support phytoplankton inputs to the oil [25].

The chromatograms indicate high concentrations of $\mathrm{n}-\mathrm{C}_{10}, \mathrm{n}-\mathrm{C}_{11}, \mathrm{n}-\mathrm{C}_{14}, \mathrm{n}-\mathrm{C}_{15}, \mathrm{n}-\mathrm{C}_{16}, \mathrm{n}-\mathrm{C}_{17}, \mathrm{n}-\mathrm{C}_{17}, \mathrm{n}-\mathrm{C}_{18}, \mathrm{n}-\mathrm{C}_{19}$, $\mathrm{n}-\mathrm{C}_{20}, \mathrm{n}-\mathrm{C}_{21}, \mathrm{n}-\mathrm{C}_{22}, \mathrm{n}-\mathrm{C}_{25}, \mathrm{n}-\mathrm{C}_{28}, \mathrm{n}-\mathrm{C}_{29}$, and $\mathrm{n}-\mathrm{C}_{30}$ for sampling point Nwata $\mathrm{A}$. Nwata $\mathrm{B}$ had $\mathrm{n}-\mathrm{C}_{10}, \mathrm{n}-\mathrm{C}_{14}, \mathrm{n}-\mathrm{C}_{15}$, $\mathrm{n}-\mathrm{C}_{16}, \mathrm{n}-\mathrm{C}_{17}, \mathrm{n}-\mathrm{C}_{17}, \mathrm{n}-\mathrm{C}_{18}, \mathrm{n}-\mathrm{C}_{19}, \mathrm{n}-\mathrm{C}_{20}, \mathrm{n}-\mathrm{C}_{21}$, and $\mathrm{n}-\mathrm{C}_{27}$.

Iron concentration of the various sampling point is very high. Values range from $363.75 \mathrm{ppm}$ to $2112.8 \mathrm{ppm}$ with Nwata 3' recorded the highest value. Nickel concentration of the sampling point is Ochani $>$ Egegaro $>$ Nwatu 3' $>$ Nwata A > Nwata B. Chromium concentration is Nwatu 3' $>$ Nwata B $>$ Egegaro $>$ Ochani $>$ Nwata A.Vanadium concentration is Ochani $>$ Egeyaro $>$ Nwata 3' $>$ Nwata A $>$ Nwata B. Lead concentration of the various sampling points range from $163 \mathrm{ppm}-10.87 \mathrm{ppm}$. Nwatu A has a higher value than Nwata B. Egeyaro recorded the highest value of $10.87 \mathrm{ppm}$. Trace metal such as iron, nickel, chromium, vanadium and lead are detected at all sampling points, the content of all trace metal increase down the stream. The iron content is very high. At the onset of anaerobic condition in most freshwater sediment, Fe (III) is the most abundant potential electron acceptor for organic matter oxidation [26]. This is in agreement with the result obtained as indicated in Table 2 having iron as the highest metal present at the site. The observed accumulation of Fe (II) during anaerobic transformation of organic materials in pristine and contaminated aquifers suggest that $\mathrm{Fe}$ (III) can be a potential electron acceptor in a wide variety of sub-surface environments and Ejamah-Ebubu oil spill site is no exception.

The vanadium/nickel ratio at various sampling points (Table 2) support the fact that V/Ni ratio is a good parameter for differentiating crude oil from various location [27].

\section{Conclusions}

One of the major prerequisites for the decontamination of crude oil contaminated sites is the knowledge of the

Table 2. Trace metal content of sampling points.

\begin{tabular}{ccccccc}
\hline Sampling point & Concentration Fe & In ppm Cr & Pb & V & Ni & V/Ni \\
\hline NwataA & $363.37 \pm 4.7$ & $2.18 \pm 0.03$ & $1.75 \pm 0.04$ & $0.08 \pm 0.02$ & $1.19 \pm 0.02$ & 0.07 \\
NwataB & $857.2 \pm 9.6$ & $4.2 \pm 0.03$ & $1.68 \pm 0.03$ & $0.06 \pm 0.01$ & $1.1 \pm 0.02$ & 0.05 \\
Nwata3 & $2112.8 \pm 6.4$ & $8.74 \pm 0.14$ & $5.85 \pm 0.08$ & $0.13 \pm 0.01$ & $2.02 \pm 0.01$ & 0.06 \\
Egeyaro & $948.27 \pm 6.9$ & $4.23 \pm 0.08$ & $10.87 \pm 0.04$ & $0.14 \pm 0.01$ & $2.08 \pm 0.02$ & 0.07 \\
Ochani & $989.17 \pm 9.6$ & $3.73 \pm 0.05$ & $3.68 \pm 0.03$ & $0.16 \pm 0.01$ & $2.21 \pm 0.02$ & 0.04
\end{tabular}


true situation or fate of hydrocarbon at the sites. Ejamah-Ebubu spill site over 40 years showed an array of distributions of polyaromatic and n-alkane hydrocarbons. Generally, there was a predominance of four - six ring polyaromatic hydrocarbons (PAHs) over the two - three ring PAHs.

Pyrene, benezo $(\mathrm{k})$ fluranthene, and benezo $(\mathrm{g}, \mathrm{h}, \mathrm{i})$ perylene are not present. There is the presence of PAHs that are classified as probably/possibly carcinogenic. The concentration of PAHs decreases down the river as one approach the Bonny River.

The n-alkane hydrocarbons (TPH) are above the EGASPIN DPR limit. The isoprenoid ratio pristane/phytane is high, even after over 40 years of oil spillage.

Remediation by enhance natural attenuation (RENA) had been suggested to be applied on the site but deep into the soil, oxygen becomes limiting. Under such conditions, anoxic or anaerobic degradation mediated by denitrifying or sulphate-reducing bacteria can become a key pathway for the cleanup of contaminated sites. The understanding of anaerobic biodegradation of aromatic compounds has increased over the past decade. Isolation of denitrifying and sulphate-reducing organisms capable of degrading toluene has led to the elucidation of several biodegradation pathways and phylogenetic relationships among bacteria strains. The type and concentration of TEAs available in a contaminated environment will affect the outcome of natural attenuation or bioremediation. Common indigenous TEAs in Ejamah-Ebubu oil spill site include nitrate, sulphate and iron.

\section{Acknowledgements}

This work was supported by OWSDW grant 2010 fund reservation No. 324021348 and PTDF postgraduate local scholarship PTDF/TR/LS/PhD/AON/215/09.

The cooperation of Ejamah Ebubu community during field sampling is hereby greatly appreciated and acknowledged. GC-FID and AAS were obtained from ANAL Concept Ltd Port Harcourt.

\section{References}

[1] Wilson, S.C. and Jones, K.C. (1993) Bioremediation of Soil Contaminated with Polynuclear Aromatic Hydrocarbons (PAHs): A Review. Environmental Pollution, 81, 229-249. http://dx.doi.org/10.1016/0269-7491(93)90206-4

[2] Mueller, J.G., Chapman, P.J., Blattmann, B.O. and Pritchard, P.H. (1990) Isolation and Characterization of a Fluoranthene Untilizing Strain of Pseudomonas paucimobilis. Applied and Environmental Microbiology, 56, 1079-1086.

[3] Miller, J.A and Miller, E.C. (1983) Some Historical Aspects of N-Aryl Carcinogens and Their Metabolic Activation. Environmental Health Perspectives, 49, 3-12. http://dx.doi.org/10.1289/ehp.83493

[4] Hall, M. and Grover, P.L. (1990) Polycyclic Aromatic Hydrocarbons Metabolism, Activation, and Tumor Initiation. In: Cooper, C.S. and Grover, P.L., Eds., Chemical Carcinogenesis and Mutagenesis 1. Handbook of Experimental Pharmacology 94:1, Springer Verlag, New York, 327-372.

[5] Kelsey, J.W. and Alexander, M. (1997) Declining Bioavailability and Inappropriate Estimation of Risk of Persistent Compounds. Environmental Toxicology and Chemistry, 16, 582-585. http://dx.doi.org/10.1002/etc.5620160327

[6] Bence, A.E. and Burns, W.A. (1995) Fingerprinting Hydrocarbons in Biological Resources of Exxon Valdez Spill Area. In: Wells, P.G., Butter, J.N. and Hughes, J.S., Eds., Exxon Valdez Oil Spill: Fate and Effect in Alaskan Waters, American Society for Testing and Materials Spech. Tech. Publ., Philadalphia, 84-140. http://dx.doi.org/10.1520/STP19862S

[7] Page, D.S., Boehm, P.D., Douglas, G.S. and Bence, E. (1995) Identification of Hydrocarbon Sources in the Benthic Sediment of the Prince William Sound and Gulf of Alaska Following the Exxon Valdez Oil Spill: Fate and Effect in Alaskan waters. American Society for Testing and Materials Spech. Tech. Publ., Philadelphia, 41-83.

[8] Douglas, G.S., Bence, A.E., Prince, R.C., McMillen, S. and Butler, E.L. (1996) The Environmental Stability of Selected Hydrocarbon Ratios. Environmental Science Technology, 30, 2332-2339. http://dx.doi.org/10.1021/es950751e

[9] Coates, J.D., Woodward, J., Allen, J., Philip, P. and Lovley, D.R. (1997) Anaerobic Degradation of Polycyclic Aromatic Hydrocarbons and Alkanes in Petroleum Contaminated Marine Harbor Sedimemts. Applied and Environmental Microbiology, 63, 3589-3593.

[10] Chaloupka, K., Harper, N. and Krishnan, V. (1993) Polyaromatic Hydrocarbon. Chemical-Biological, 89, $141-158$.

[11] Allen, S.E., Grinshaw, H.M., Parkinson, S.A. and Quarmly, C. (1984) Chemical Analysis of Ecological Material. Blackwell Scientific Publication, Oxford.

[12] APHA (1985) Standard Methods for the Examination of Wastewater and Water. 19th Edition, American Public Health Association, Washington DC.

[13] Atlas, R.M. (1984) Petroleum Microbiology. Macmillan Publishing Company, New York. 
[14] Leahy, J.G. and Colwell, R.R. (1990) Microbial Degradation of Hydrocarbons in the Environment. Microbiological Reviews, 54, 305-315.

[15] Rosenbery, E. and Ron, E.Z. (1996) Bioremediation of Petroleum Contamination. In: Crawford, R.L. and Crawford, D.L., Eds., Bioremediation: Principles and Applications, Cambridge University Press, Cambridge, 100-124. http://dx.doi.org/10.1017/CBO9780511608414.006

[16] Meckenstock, R.U., Annweiler, E., Michaelis, W., Richnow, H.H. and Schink, B. (2000) Anaerobic Naphthalene Degradation by a Sulphate-Reducing Enrichment Culture. Applied and Environmental Microbiology, 66, 2743-2747. http://dx.doi.org/10.1128/AEM.66.7.2743-2747.2000

[17] (2002) Environmental Guidelines and Standards for the Petroleum Industry in Nigeria (EGSPIN). Environmental Remediation Manual, Department of Petroleum Resources (DPR), Lagos.

[18] Wilike, W. (2000) Polycyclic Aromatic Hydrocarbons (PAHs) in Soil-A Review. Journal of Plant Nutrition and Soil Science, 163, 229-248. http://dx.doi.org/10.1002/1522-2624(200006)163:3<229::AID-JPLN229>3.0.CO;2-6

[19] (2007) IARC Monograph on the Evaluation of the Carcinogenic Risk of Chemicals to Humans, Vol. 32, Polycyclic Aromatic Hydrocarbon, Part 1, Chemical, Environmental and Experimental Data. International Agency for Research on Cancer (IARC), Lyon, 1-55.

[20] Boll, E.S., Christensen, J.H. and Holm, P.E. (2008) Quantification and Source Identification of Polycyclic Aromatic Hydrocarbon in Sediment, Soil, and Water Spinach from Hanoi, Vietnam. Journal of Environmental Monitoring, 10, 261-269. http://dx.doi.org/10.1039/B712809F

[21] Atlas, R.M. (1995) Microorganism in Our World. Mosby Yearbook Inc., USA.

[22] National Academy of Sciences (1985) Oil in Sea: Inputs, Fates and Effects. National Academy Press, Washington DC.

[23] Peters, J. and Moldowan, J.M. (1993) The Biomarker Guide: Interpreting Molecular Fossils in Petroleum and Ancient Sediments. Prentice-Hall, Englewood Cliffs.

[24] Prince, R.C., Elmendorf, D.L., Lute, J.R., Hsu, C.S., Haith, C.E., Senius, J.D., Dechert, G.J., Douglas, G.S. and Bulter, E.L. (1994) $17 \alpha(\mathrm{H}), 24 \beta(\mathrm{H})$-Hopane as a Conserved Internal Marker for Estimating the Biogradation of Crude Oil. Environmental Science Technology, 28, 142-145. http://dx.doi.org/10.1021/es00050a019

[25] Osuji, L.C. and Achugasim. O. (2007) Environmental Degradation of Polluting Aromatic and Aliphatic Hydrocarbons: A Case Study. Chemistry \& Biodiversity, 4, 424-430.

[26] Lovley, D.R., Baedecker, M.J., Lonergan, D.J., Cozzarelli, I.M., Philips, E.J.P. and Siegel, D.I. (1989) Oxidation of Aromatic Contaminants Coupled to Microbial Iron Reduction. Nature, 339, 297-300. http://dx.doi.org/10.1038/339297a0

[27] Nwadinigwe, C.A. and Nwaorgu, O.N. (1999) Metal Contaminants in Some Nigeria Well-Head Crudes: Comparative Analysis. Journal of the Chemical Society, 24, 118-121. 